American Journal of Engineering and Applied Sciences, 2012, 5 (2), 128-131

ISSN: 1941-7020

(C) 2014 N.A. Hadi et al., This open access article is distributed under a Creative Commons Attribution

(CC-BY) 3.0 license

doi:10.3844/ajeassp.2012.128.131 Published Online 5 (2) 2012 (http://www.thescipub.com/ajeas.toc)

\title{
Dry Heating of Palm Fruits: Effect on Selected Parameters
}

\author{
Nu'man Abdul Hadi, \\ Ng Mei Han, Choo Yuen May and Ma Ah Ngan
}

Engineering and Processing Research Division, Malaysian Palm Oil Board, 6, Persiaran Institusi, Bandar Baru Bangi, 43000 Kajang, Selangor, Malaysia

Received 2011-12-27, Revised 2012-07-15; Accepted 2012-08-01

\begin{abstract}
This study reports on the effects of dry heating of oil palm fruits for the purpose of sterilization and solvent extraction with various oil parameters. Steam sterilization of oil palm fresh fruit bunches was required as a pre-treatment to deactivate enzymes that give rise to Free Fatty Acids (FFA) before the oil could be extracted. While the use of high-pressure steam was effective, large amount of water used ends up as palm oil mill effluent, which requires appropriate treatment. Dry heating of oil palm fruits was carried out in an oven for 1-4 and 5 min time duration. The heated fruits were extracted for its oil by solvent means. Oil yield, Deterioration Of Bleachability Index (DOBI), oxidative stability and FFA content were investigated. The FFA content in the oil extracted from dry heated oil palm fruits ranged from 1.02-2.19\%, DOBI from 4.19-6.72 and oxidative stability from 14.3-19.1 h. Dry heated oil palm fruits yield crude oil with comparable quality to that of commercial crude palm oil, which is steam sterilized.
\end{abstract}

Keywords: Dry Heating, Sterilization, Palm Fruit, Palm Oil, Free Fatty Acid, Bleachability Index, Oxidative Stability

\section{INTRODUCTION}

In current palm oil milling, Fresh Fruit Bunches (FFB) are sterilized under high pressure steam. The main objectives of sterilization are to supply heat to detach the fruits from FFB stalks, stop enzyme reaction that cause Free Fatty Acids (FFA) in the oil to rise and condition the nuts for subsequent cracking (Vijaya et al., 2010). Currently large quantities of steam are used and prolonged steaming is necessary to achieve sufficient heating of the inner layers of the bulky FFB. The time required for steam sterilization depends on the total weight of FFB. It requires about 25-30 min for small bunches (3-6 kg) and about $50 \mathrm{~min}$ for bunches more than $7 \mathrm{~kg}$ (MKPUM, 1985). Almost one-half of the steam used is exhausted during the sterilization cycle and the remaining steam ends up as sterilizer condensate and forms part of the Palm Oil Mill Effluent (POME), which requires rigorous treatment to comply with stringent discharge standards of the Malaysian Department of Environment (DOE) (Ma, 1999).
Chow demonstrated that dry heating of oil palm fruits is able to achieve the objectives of conventional steam sterilization (Chow and Ma, 2007). However, it works only for the outer layer of fruits of the FFB and prolonged heating severely damages the fruits and kernels (Chow and Ma, 2007). Although majority of the oil is contained in the mesocarp, the kernels yield another type of oil, palm kernel oil. Hence, heating the fruits to halt the enzymatic reaction while preserving the kernel is a major concern in palm oil milling.

While crude palm oil is obtained in conventional palm oil milling through screw pressing, solvent extraction is also gaining popularity. Solvent extraction has been practiced in the extraction of oil from soybeans, sunflower seeds, rapeseed, corn and palm kernels, as well as pressed palm fibre (Stein and Glaser, 1976). Solvent extraction gives higher yields than conventional screw pressing. This study reports on a technique for dry heating and solvent extraction of oil palm fruits. The 
combination of these practices reduces the long sterilization time as well as increases oil yield.

\section{MATERIALS AND METHODS}

\subsection{Materials}

All solvents and chemicals used were of analytical and chromatographic grades, purchased from Merck (Hesse, Germany), J.T. Baker (New Jersey, USA), R and M (Essex, United Kingdom.), Univar (New South Wales, Australia) and Mallinckrodt (New Jersey, USA). Oil palm fruits and commercial crude palm were obtained from Palm Oil Milling Technology Centre (POMTEC) of Malaysian Palm Oil Board (MPOB) in Negeri Sembilan, Malaysia.

\subsection{Processing Palm Fruitlets}

Oil palm fruits obtained from the mill were heated under dry condition using a National NN-6850 oven. Heating time was varied from $1-$ and $5 \mathrm{~min}$. The heated oil palm fruits were peeled and the nuts were removed from the fruit mesocarp. Oil was extracted with hexane for $2 \mathrm{~h}$ by using a Soxhlet extractor, at a solvent to fruit ratio of 1.6-1 $(\mathrm{v} / \mathrm{w})$. The solvent was then removed from the oil by using a rotary evaporator. The same procedure was repeated for the dry heated fruits that have been heated two days prior and kept.

\subsection{Oil Quality Analyses}

Free Fatty Acid (FFA) content of the oil was determined by using the PORIM Test Method (Loh et al., 2006). Sodium hydroxide solution of $0.02 \mathrm{M}$ was prepared and standardized with potassium hydrogen phthalate. A known mass of the oil sample was dissolved in neutralized iso-propanol and the free acids were neutralized with sodium hydroxide. FFA values were expressed as palmitic acid (\%).

Deterioration of Bleachability Index (DOBI) was determined by using the PORIM test method (Loh et al., 2006). The method developed by (Swoboda, 1982), defines
DOBI as the ratio of the spectrophotometric absorbance at $446 \mathrm{~nm}$ to that at $269 \mathrm{~nm}$. A known mass of the oil was dissolved in n-hexane (95\%) and the absorbance reading at 446 and $269 \mathrm{~nm}$ was taken using Thermo Fisher Scientific Spectrophotometer (Madison, Wisconsin, USA).

The Rancimat method was used to determine oxidative stability (Michael and Eltigani, 1994) by using a Metrohm 743 Rancimat (Herisau, Appenzell Ausserrhoden, Switzerland). A $2.50 \mathrm{~g}$ oil sample was prepared in a reaction vessel and placed in a heating block. The block temperature and air flow were set at $120^{\circ} \mathrm{C}$ and $10 \mathrm{~L} \mathrm{~h}^{-1}$ respectively. The time for the oil sample to fully oxidize was recorded.

\section{RESULTS}

Parameters analysed in the dry heating of oil palm fruits were presented separately, showed in variation of heating duration from 1-5 mins. The resulted effect of leaving the heated fruits for two days before the extraction of oil was showed in the same figure for each parameters.

Table 1 shows the condition of the oil palm fruits upon dry heating. Figure 1 shows the oil yield of the dry-heated oil palm fruits by way of solvent extraction. Oil yield (\%) calculated is a function of the amount of oil extracted to the weight of fruits.

Figure 2-4 show the results of Free Fatty Acid (FFA) content, Deterioration Of Bleachability Index (DOBI) and oxidative stability of oil extracted from the dry heated fruits; respectively.

Table 1. Condition of the oil palm fruits upon dry heating

\begin{tabular}{lll}
\hline Heating time $(\mathrm{min})$ & Mesocarp & Kernel \\
\hline 1 & Oily/soft & White \\
2 & Oily/soft & White \\
3 & Oily/soft & White \\
4 & Half dried & Slightly browned \\
5 & Dried/hard & Completely browned \\
\hline
\end{tabular}

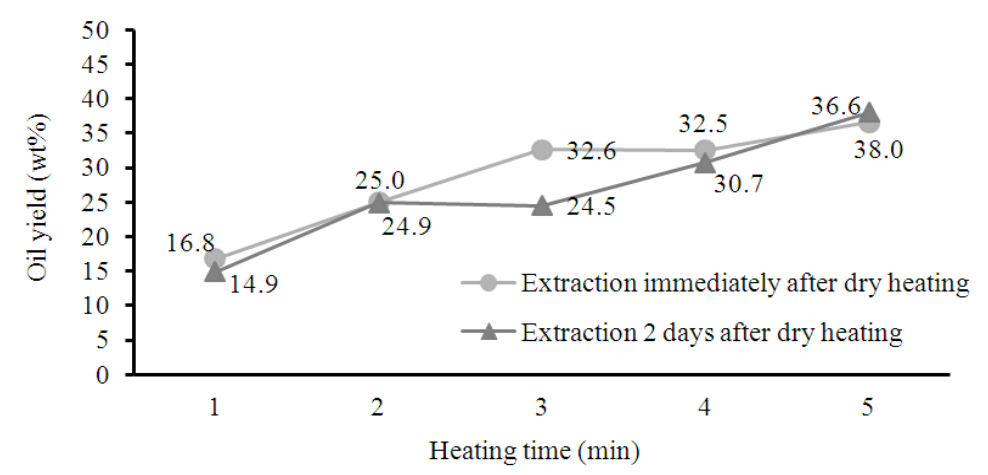

Fig. 1. Oil yield from dry-heated oil palm fruits 
Nu'man Abdul Hadi et al. / American Journal of Engineering and Applied Sciences 5 (2) (2012) 128-131

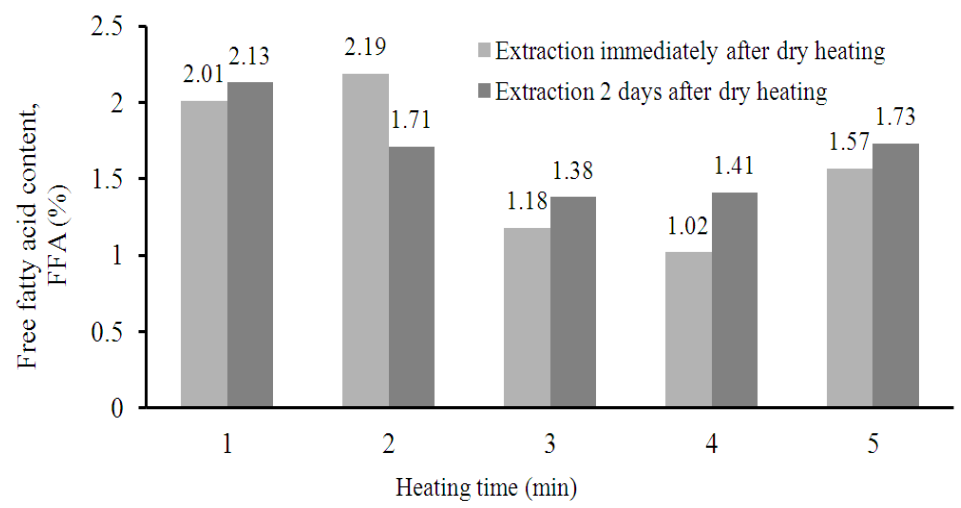

Fig. 2. Free fatty acid content in oil extracted from dry-heated oil palm fruits

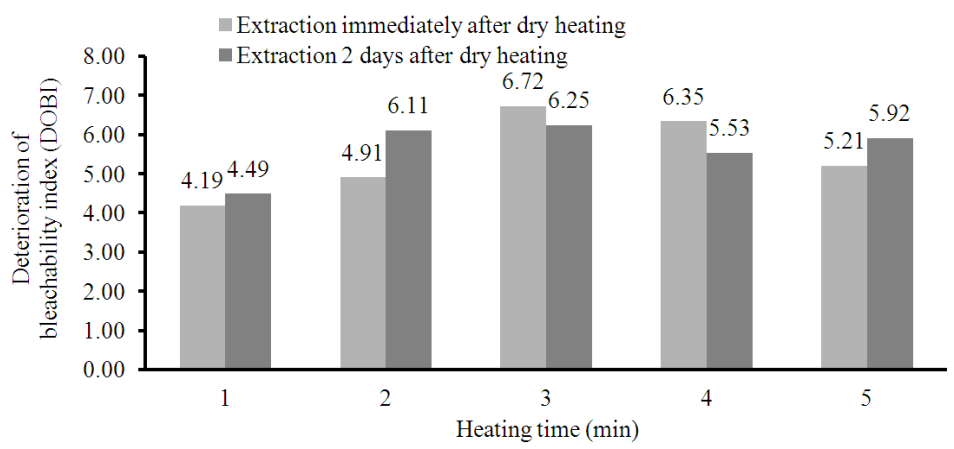

Fig. 3. Deterioration of bleachability index of oil extracted from dry-heated oil palm fruits

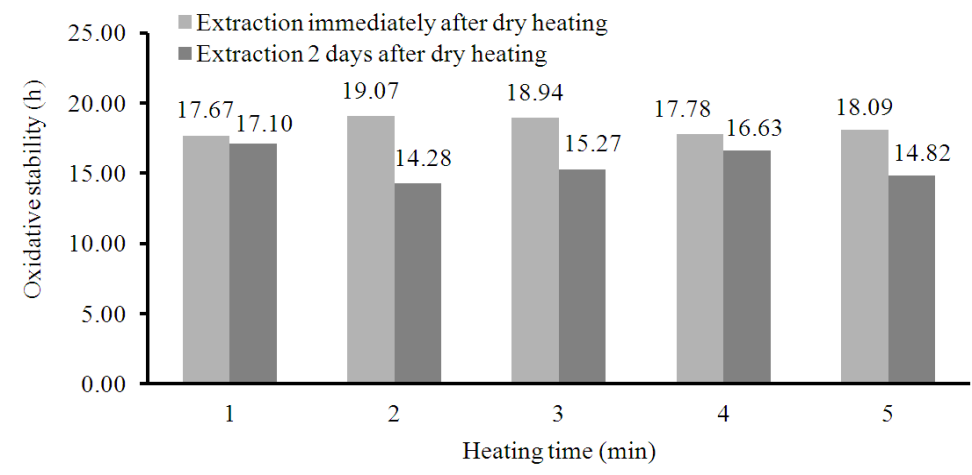

Fig. 4. Oxidative stability of oil extracted from dry-heated oil palm fruits

\section{DISCUSSION}

Dry heating exposed the oil palm fruits to potential burning. The heating duration played a crucial part in ensuring the heated fruits remained in good condition for oil extraction. The oil yield showed the efficiency of the solvent extraction procedure and the effect of dry heating on the oil content of the fruits.
Heat penetration is the key factor in sterilization of palm fruitlets under dry heating. Figure 1 shows that the oil yield increased with increasing heating time. In this respect, the mesocarp is conditioned in a short period of time without affecting the kernel. Long heating time caused the kernel to be overcooked as indicated in Table $\mathbf{1}$, even though the oil yield is high. In addition, hardened mesocarps make the depericarping operations difficult. 
Moderate heating time of 2-3 min was optimum to loosen the nut from its mesocarp, while keeping the kernel in good condition for further processing.

Malaysian Palm Oil Association (MPOA), previously known as Malaysian Oil Palm Growers' Council (MPOGC) established that the FFA content in Crude Palm Oil (CPO) for trading purpose must not exceed 5\% (Nor'aini and Siew, 1990). When the bunch is cut during fruit harvesting, enzymes start to catalyze and breaking down the triglycerides into FFA and partial glycerides. The increasing FFA deteriorates the crude oil. Thus, it is important to keep the FFA content as low as possible. The average FFA content in commercial CPO is ca. $3.4 \%$. The FFA content in the dry-heated oil palm fruits ranged from 1.02-2.19\%. These amounts are much lower than the limit specified by the MPOA and lower than those of typical commercial CPO. In addition, FFA in oil extracted from fruits right after dry heating did not differ much from the FFA content in oil extracted two days after heating. This shows that dry heating was able to completely halt the enzymatic reaction that leads to the rise in FFA.

CPO needs to be refined, bleached and deodorized before it can be consumed. Thus, it is important for refiners to know the quality of incoming CPO. Quality of CPO can be described by many well-established oxidation parameters, but the deterioration of bleach ability index or DOBI is the most reliable tool to predict the ease of refining (Lin, 2001). Knowing the DOBI value allows refiners to establish the required amount of bleaching earth for refining the oil to acceptable color to consumers and food manufacturers. In a palm oil mill, DOBI of commercial CPO is graded as poor (1.78-2.30), fair (2.31-2.92), good (2.93-3.24) and excellent quality of CPO will have DOBI above 3.24 (Lin, 2001). The DOBI values of oil extracted from dry heated oil palm fruits is depicted in Figure 3, with the minimum being 4.19. This clearly shows that the oil extracted from dryheated fruits has excellent quality. Although DOBI is affected by the ripeness of the palm fruit, other factors during sterilization, such as contamination of CPO with sterilizer condensate and prolonged steam sterilization, will also affect the DOBI value, thus, gives dry heating an advantage where DOBI is concern.

Oxidative stability is defined as stability of an atom's oxidation number, or the stability of the number of electrons of an atom. In palm oil industry, it is best defined as the ability of palm oil to resist the oxidation process due to prolonged heating at high temperature $\left(120^{\circ} \mathrm{C}\right)$. Figure 4 shows that the Rancimat oxidative stability of oil extracted from dry heated palm fruits varied between 14.2-19.1 h. This is comparable to that of CPO, which is about $15.9 \mathrm{~h}$. In a separate paper which determined the correlation between the oil stability and the DOBI, lower Rancimat values coincided with lower DOBI values (Lin, 2001). In this study, Rancimat oxidative stability was also in parallel with DOBI.

\section{CONCLUSION}

Dry heating of oil palm fruits at 3 min duration was able to halt the enzymatic reaction that causes the FFA to rise, loosen the nut from its shell and preserves the condition of its kernel. Quality of oil extracted from the mesocarp is similar, if not better, than the commercial CPO obtained from steam-sterilized fruits. Plus, dry heating will be able to greatly reduces, if not eliminates the usage of water during the milling process.

\section{AKCNOWLEDGEMENT}

The researcher would like to thank the Director General of MPOB for the financial support and permission to publish this study. Thanks also to the staffs of Engineering and Processing Research Division, MPOB for their assistance.

\section{REFERENCES}

Chow, M.C. and A.N. Ma, 2007. Processing of fresh palm fruits using microwaves. J. Microwave Power Electromagnetic Energy, 40: 165-173.

Lin, S.W., 2001. Deterioration of bleachability index. Inform. AOCS., 12: 1183-1187.

Loh, S.K., S.F. Cheng, Y.M. Choo and A.N. Ma, 2006. A study of residual oils recovered from spent bleaching earth: Their characteristics and applications. Am. J Applied Sci., 3: 2063-2067. DOI: 10.3844/ajassp.2006.2063.2067

Ma, A.N., 1999. Environmental management for the palm oil industry. Palm Oil Dev.

Michael, H.G. and M. Eltigani, 1994. A comparison of oil stability based on the metrohm rancimat with storage at $20^{\circ} \mathrm{C}$. J. Am. Oil Chem. Soc., 71: 649651. DOI: 10.1007/BF02540595

MKPUM, 1985. Palm Oil Factory Process Handbook. 1st Edn., Institiut Penyelidikan Minyak Kelapa Sawit Malaysia, Kuala Lumpur, ISBN-10: 9679610071, pp: 109.

Nor'aini, S. and W.L. Siew, 1990. Quality control measures in the palm oil industry. Palm Oil Dev.

Stein, W. and F.W. Glaser, 1976. Continuous solvent extraction of sunflower, seed, groundnuts, palmkernels, rapeseed and copra. J. Am. Oil Chem. Soc., 53: 283-285. DOI: 10.1007/BF02605702

Swoboda, P.A.T., 1982. Bleachability and the DOBI (determination of bleachability index in palm oil). PORIM Bull., 5: 28-38.

Vijaya, S., Y.M. Choo, H. Muhammad, Z. Hashim and A.T. Yew et al., 2010. Life cycle assesment of the production of crude palm oil (Part 3). J. Oil Palm Res., 22: 895-903. 